\title{
EDITORIAL
}

\section{LIEUTENANT-COLONEL FREDERICK SAMUEL HEUSTON, R.A.M.C.}

(1857-1914)

IT will not have escaped the notice of our readers that the editorials which stem from our pen are of a general nature. To those who are unkind enough to ascribe this pattern to the Editor's ignorance of medical science may we say that we feel the Journal is already full enough of professional material to satisfy the keenest of practitioners and that something less heavy and more light-hearted may not on occasion come amiss.

We were chewing the end of our pen the other evening trying to decide on what to write our next Editorial when we were interrupted by Pompey-the family's Pekedemanding to be taken for a walk. Following Sir Isaac Newton's example we merely said "Ah Prince (Pompey) how little doest thou know etc." and went forth. But on our return we did realise what Pompey had done- he had provided the subject for an Editorial.

Most of our readers will be aware that Pekes belong to one of the oldest breed of dogs, but that they were almost unknown in the Western World until the last hundred years on account of the prohibition (on pain of death) of their removal from the Royal Palaces of China where they were reserved exclusively for the Royal family. What readers may not know is that it was mainly due to the British Army and in particular to an R.A.M.C. officer that Pekes were introduced to the West. We feel that this contribution to our life and times is of sufficient interest to be put on record in the Journal.

It was in 1860 , following the sack of the Summer Palace in Peking, that five or so of the palace dogs were brought to England. Amongst them was a superb little fawn and white bitch which General Dunne presented to Queen Victoria. In view of the dog's past adventures the General aptly named her Looty. Whether the Queen shared the General's sense of humour is not recorded. But the first European ever to be given a pair of Pekinese dogs was Lieutenant-Colonel Heuston, R.A.M.C., the subject of our Editorial.

Frederick Samuel Heuston was born in 1857 and after qualifying in medicine in Dublin joined the Army Medical Department in 1884. He distinguished himself in the Hazara Expedition of 1888 and from 1894-1898 was specially seconded for service under the Chinese Government. He next saw extensive service in the Boer War for which he was awarded the C.M.G. Thereafter he served as Surgeon and Physician to the Royal Hospital, Kilmainham where he remained until he retired in 1912. He died at Greystones, Dublin in 1914.

During his service in China (1894-98) he gained the gratitude and affection of the Chinese Government and was one of the few Europeans ever to be awarded the much coveted Order of the Double Dragon. He became the Professor of Medicine in the Imperial Medical College, Tientsin where he was most successful in raising the standards of instruction. As the ultimate sign of the Royal favour he was presented with a pair of Pekinese dogs - the first European ever to be so honoured. These two (named Chang and Lady $\mathrm{Li}$ ) were sent home ahead of Heuston to the house of his twin brother in Greystones, Co. Wicklow. The first litter was born in the stables, and drowned on the recommendation of a groom as "terrible little Chinese monsters unfit for the Missus 
to see!" It has been estimated (needless to say by a Scot for only a member of that race could gain satisfaction from so gloomy an exercise), that the drowning of this and subsequent litters deprived the world of some hundred thousand pound's worth of blood stock Pekes! Fortunately Heuston returned home in time to ensure the survival of the later puppies and thus help to confirm the United Kingdom as the acknowledged centre of Peke breeding.

We were interested to observe that even after 70 years Heuston's example is still being followed for at a recent Corps Sports Day in Mytchett we noted five proud owners -three Major-Generals, one Brigadier and one Major!

\section{Colonel Commandant R.A.M.C.}

Brigadier R. J. Niven, M.C., M.B., D.P.H., has been appointed Colonel Commandant R.A.M.C., with effect from 26 July 1972, in succession to Major-General J. C. Barnetson.

\section{Consultant Emeritus}

Mr. J. B. Blaikley, C.B.E., F.R.C.S., F.R.C.O.G., has been appointed Consultant Emeritus to the Army.

\section{Honorary Consultant}

Dr. T. A. Kemp, M.D., F.R.C.P., has been appointed Honorary Consultant Physician to the Army, in succession to Sir Ronald Bodley Scott. 